\title{
PENGARUH PENGGUNAAN PETA KONSEP TERHADAP PENINGKATAN DAYA ANALISIS MAHASISWA (Studi Eksperimen pada Perkuliahan Perencanaan Pembelajaran Geografi Tahun Akademik 2012/2013)
}

\author{
${ }^{1}$ Asep Mulyadi, Jurusan Pendidikan Geografi, FPIPS, UPI \\ ${ }^{2}$ Ahmad Yani, Jurusan Pendidikan Geografi, FPIPS, UPI
}

\begin{abstract}
ABSTRAK
Penelitian ini bertujuan ingin mengetahui pengaruh penggunaan peta konsep terhadap peningkatan daya analisis mahasiswa pada materi perkuliahan Perencanaan Pembelajaran Geografi pada Jurusan Pendidikan Geografi FPIPS UPI. Pemanfaatan model pembelajaran peta konsep (concept map) dalam pembelajaran diyakini akan berpengaruh terhadap kemampuan seseorang dalam proses menganalisis sesuatu yang sedang dikajinya. Semakin banyak konsep yang dilibatkan dalam peta konsep dan terhubung satu sama lain, maka semakin tinggi kemampuan seseorang dalam menganalisis sesuatu yang dikajinya. Metode yang digunakan adalah eksperimen tipe kuasi eksperimen (nonequivalent control group design), dimana kelompok eksperimen maupun kelompok koktrol tidak dipilih secara random. Penelitian dilakukan pada kelas pararel, dimana satu kelas dijadikan kelas kontrol dan lainnya sebagai kelas ekperimen. Hipotesis yang diajukan adalah terdapat perbedaan, yakni kelompok mahasiswa yang mendapat perlakuan, memiliki kemampuan daya analisis yang lebih baik daripada mahasiswa kelompok kontrol. Hasil penelitian menunjukkan sebagai berikut Hasil uji statistic menunjukkan nilai t hitung sebesar 3,042, sedangkan t tabel 2,029, sehingga $t$ hitung lebih besar dari t tabel. Ini berarti Ho ditolak dan Ha diterima. Dari kolom Uji t menunjukkan nilai $P=0,003$ untuk uji dua sisi (2-tailed). Karena nilai $P$ lebih kecil dari nilai $\alpha=0,05$, maka Ho ditolak dan Ha diterima, sehingga terdapat perbedaan antara kelas eksperimen dengan kelas kontrol setelah diaplikasilan model peta konsep pada kelas eksperimen. Rata-rata selisih nilai pre test dan post test pada kelas $(1,8108)$ eksperimen lebih besar daripada kelas kontrol (0,2162). Dengan demikian, dapat disimpulkan atau dapat dikatakan penggunaan model peta konsep berpengaruh sangat signifikan terhadap hasil belajar mahasiswa.
\end{abstract}

Kata kunci: peta konsep (concept map), belajar bermakna, daya analisis.

\section{PENDAHULUAN}

Kebermaknaan belajar adalah pembelajaran yang menghubungkan atau mengkaitkan informasi itu pada pengetahuan yang dimilikinya (Dahar, 2011). Ketika orang mampu menghubungkan informasi awal yang telah diketahui sebelumnya dengan pengetahuan yang baru, maka itulah yang dikatakan sebagai pengetahuan yang bermakna. Dengan demikian, belajar akan dikatakan bermakna jika peserta didik mampu mengaitkan pengetahuan awal yang dimilikinya dengan informasi baru. Proses seseorang dalam menghubungkan antar konsep yang telah diketahuinya dapat terlihat ketika ia menggambarkannya dalam peta konsep (concept map). Dalam makna yang lain, peta konsep dapat membantu peserta didik untuk melihat perkembangan kebermaknaan belajarnya baik di kelas maupun di luar kelas.

Apa yang disebut konsep? Sagala (2005) mengatakan bahwa konsep merupakan buah pemikiran seseorang atau sekelompok orang yang dinyatakan dalam definisi sehingga 
melahirkan produk pengetahuan meliputi prinsip, hukum, dan teori. Kardi dalam Trianto (2011) mendefinisikn konsep sebagai suatu abstraksi dari serangkaian pengalaman yang didefenisikan sebagai suatu kelompok objek atau kejadian. Kebermaknaan sesuatu pada dasarnya bersifat individual. Peta konsep yang dikembangkan oleh seseorang tidak akan sama dengan peta konsep yang dikembangkan oleh orang lain walaupun dari satu wacana (informasi) yang sama. Selanjutnya, Dahar (2011) mengatakan, bagaimana pun bentuk dari sebuah peta konsep akan memperlihatkan kaitan-kaitan yang bermakna bagi orang yang menyusunnya, dengan kata lain kebermaknaan konsep-konsep khas bagi setiap orang.

Kaitannya dengan proses belajar melalui peta konsep, Ausubel dalam Dahar (2011) mengemukakan bahwa belajar dapat diklasifikasikan dalam dua dimensi. Dimensi pertama berhubungan dengan cara penyampaian materi pelajaran, apakah melalui penerimaan atau penemuan. Dimensi kedua menyangkut cara bagaimana peserta didik dapat mengaitkan informasi-informasi itu pada struktur kognitif yang telah ada sehingga terjadi belajar bermakna. Ketika seorang peserta tidak mampu mengaitkan informasi-informasi pada struktur kognitifnya yang telah ada sebelumnya maka sering kita sebut sebagai proses belajar menghafal. Hasil belajar dengan cara dihafal adalah ketika peserta didik mampu menyebutkan suatu konsep tetapi ia sendiri tidak memahami arti konsep yang disebutkannya. Peserta didik yang mampu menyebutkan suatu konsep, tetapi tidak memahami akan konsep itu

\section{TINJAUAN PUSTAKA \\ Teori Belajar dan Peta Konsep}

Belajar merupakan proses berpikir, yaitu proses aktif pengolahan data dan informasi yang berlangsung pada pihak yang sedang belajar. Peserta didik yang sedang belajar akan dianggap sebagai subjek yang aktif dalam mencari dan menanggapi stimulus yang muncul dihadapannya. Suparno (2001) mengutip pendapat Jean Peaget bahwa peserta didik memperoleh pemahaman tentang objek yang ada di lingkungannya melalui proses asimilasi dan akomodasi. maka itulah yang disebut "belajar tanpa makna". Kemampuan orang dalam memaknai suatu konsep adalah "modal" untuk menjelaskan, menganalisis, dan mengevaluasi tentang konsep tersebut dan akan mampu mengaitkan dengan konsep-konsep lainnya yang terhubung secara rasional. Dengan demikian, jika seseorang tidak memahami jaringan koneksi antar konsep pada skema kognitifnya, maka ia tidak akan mampu menjelaskan, menganalisis, / mengevaluasinya.

Berdasarkan asumsi di atas, peneliti mengajukan hipotesis bahwa pemanfaatan peta konsep dalam pembelajaran akan berpengaruh terhadap kemampuan seseorang dalam proses menganalisis sesuatu yang sedang dikajinya. Semakin banyak konsep yang dilibatkan dalam peta konsep dan terhubung satu sama lain, maka semakin tinggi kemampuan seseorang tersebut dalam menganalisis sesuatu yang dikajinya.

Mahasiswa adalah peserta didik yang dituntut untuk mampu menganalisis setiap masalah yang dihadapi dalam perkuliahan. Tahap berpikir analisis merupakan tahap berpikir tingkat tinggi yang perlu dibina di kalangan mahasiswa. Namun demikian, tidak setiap mahasiswa memiliki keterampilan yang sama dalam berpikir. Tinggi rendahnya kemampuan analisis mahasiswa bersifat relatif dan belum ditemukan hasil penelitian tentang tingkat kemampuan analisis mahasiswa, namun yang pasti kemampuan analisis mahasiswa di setiap matakuliah perlu ditingkatkan. Berdasarkan uraian di atas, maka salah satu teknik yang dianggap membantu menakar, meningkatkan, dan mengevaluasi daya analisis mahasiswa adalah teknik peta konsep.

Asimilasi adalah proses menghubungkan objek dengan konsep yang sudah ada dalam pikiran sedangkan akomodasi adalah proses memanfaatkan konsep-konsep dalam pikiran untuk menafsirkan objek. Kedua proses tersebut berangsung secara terus menerus sehingga membuat pengetahuan lama dan pengetahuan baru menjadi seimbang. Tidak hanya itu, secara bertahap peserta didik dapat membangun pengetahuan dan pemahaman terhadap lingkungannya. Konsep yang dapat memperkaya pengetahuan akan diadopsi melalui proses asimilasi, jika kontradiktif atau berbeda dengan 
pengetahuan lama, maka akan diawali dengan proses akomodasi.

Agar peserta didik dapat belajar secara optimal, Dollard dan Miller dalam Hergenhahn dan Olson (2008) menyarankan untuk mengkondisikan terjadinya learning dilemma yaitu kondisi keraguan sehingga diajukan pertanyaan yang perlu dicari jawabannya. Dalam prakteknya guru mengajukan pertanyaan yang menarik perhatian peserta didik. Dengan pertanyaan tersebut, guru juga yang menjawabnya. Pada saat jawaban itu dikemukakan dan dipahami oleh peserta didik, maka terjadilah asimilasi dan pada saat itu bertambah pula pengetahuan peserta didik.

Piaget dan para pendukung teori kognitif memiliki suatu keyakinan bahwa proses belajar terjadi pada aspek kognitif yang berproses di otak atau pikiran. Kerja otak menurut Buzan (2008) dapat dibuat peta yang disebut peta konsep. Peta konsep dapat dijadikan instrumen penelusuran terjadinya proses asimilasi dan akomodasi.

Melalui peta konsep, seseorang dapat diuji kemampuannya dalam bernalar atau melakukan analisis. Konsep tentang proses asimilasi dan akomodasi sebenarnya erat kaitannya dengan teori pembelajaran kognitif karena dapat terlihat pertumbuhan pengetahuannya melalui peta konsep. Sebagaimana telah disinggung pada pendahuluan atau pada bagian awal artikel ini, ketika seseorang memperoleh pengetahuan baru, maka proses belajar yang bersangkutan dikatakan telah bermakna.

Byungro Lim (1999) pada situs milik Charles M. Reigeluth Credit mengatakan bahwa pembelajaran bermakna merupakan pembelajaran ke arah kepemahaman (understood) terhadap sesuatu. Pemahaman akan terjadi ketika antar konsep yang telah dimiliki saling terhubung atau saling berhubungan satu dan lainnya. Dalam proses pembelajaran, teori kognitif menyarankan agar guru atau dosen berperan sebagai fasilitator yang membantu siswa untuk memahami apa yang sedang dipelajari mahasiswa. Media yang digunakan dapat bermacam ragam dan tidak dapat dibatasi, yang penting memungkinkan siswa untuk mencari, menganalisis dan menginterpretasi informasi yang diperolehnya menjadi miliknya.
Langkah pembelajaran yang lebih praktis dan cukup menarik dalam teori kogntif sebenarnya dari Novak (1998) dalam bukunya Learning, Creating, and using Knowledge yang memberi rambu-rambu penerapan model pembelajaran bermakna. Menurutnya, model ini akan berhasil jika siswa mampu mengkaitkan informasi yang telah dimilikinya dengan informasi barunya. Berbeda dengan teknik belajar dengan cara menghafal, siswa hanya mencoba mengingat informasi yang dianggap baru tanpa mengkaitkan dengan pengetahuan yang telah dimilikinya.

Berdasarkan prinsip dasar tersebut, maka pembelajaran bermakna menurut Novak (1998) memiliki tiga persyaratan yaitu: (a) relevan dengan pengetahuan yang telah diketahui siswa, artinya kedudukan pengetahuan yang telah diketahui siswa, sesederhana apapun tentang sesuatu tidak dapat dianggap sepele. Implikasnya, guru perlu mengetahui posisi pengetahuan siswa sebelum memulai proses pembelajaran, (b) Materi yang diajarkan bermakna bagi siswa. Dalam hal ini, pengetahuan yang dipelajari siswa memiliki kaitan yang berarti dengan ilmu pengetahuan lainnya dan isi materi harus nyata baik konsep maupun dalilnya, (c) peserta didik harus memutuskan tentang kebermaknaan belajar bagi dirinya. Artinya, siswa harus sadar dan menyengaja mengkaitkan pengetahuan baru dengan pengetahuan yang telah dimilikinya.

Bagaimana cara menyusun peta konsep? Peta pikiran adalah salah suatu teknik penggambarkan skema pengetahuan yang dimiliki oleh seseorang dalam satu halaman gambar bagan alir atau gambar koneksi antar konsep. Teknik peta pikiran mulai dikembangkan pada 1970-an oleh Tony Buzan yang didasarkan pada cara kerja otak. Peta pikiran menggunakan pengingat-pengikat bentuk visual dan sensorik dalam suatu pola dari ide-ide yang berkaitan, seperti peta jalan yang digunakan untuk belajar, mengorgansasi dan merencanakan (DePorter dan Hernacki, 1999; 152). Dengan demikian, dapat disimpulkan atau dapat dikatakan metode ini dapat membangkitkan ide-ide orisinal dan memicu ingatan yang mudah, menyenangkan, dan kreatif. 
Hernowo (2005) mengatakan bahwa mapping concept atau dikenal pula mind map (peta pikiran) adalah alat yang dapat memetakan jaringan pikiran sesorang sehingga dapat melahirkan gagasan baru. Hernowo mengatakan bahwa mind map lebih baik daripada menggunaan teknik outlining (membuat outline). Lewat pemetaan, pikiran kita dapat diajak untuk mengeksplorasi sampai sejauhjauhnya apa yang disimpan oleh kita sendiri. Cara memetakan pikiran yang diaplikasikan untuk pemetaan masalah yang perlu dipecahkan diawali dengan menancapkan satu topik masalah, lalu mulai menjalar ke berbagai sudut dengan cara membuat garis dan simbol-simbol visual yang mengingatkan kita pada pengalaman di masa lalu (imajinasi reproduktif) atau pada wujud imajinasi produktif. Dari pusat titik ikat, menyebar menjadi empat cabang, sampai setiap cabang terdapat ranting-ranting.

Dalam banyak kajian, peta konsep sangat populer. Jenis peta konsep yang digagas banyak orang antara lain sebagai berikut.

a. Pohon Jaringan (Network Tree)

Peta konsep jenis pohon jaringan dimulai dari gagasan atau tema pokok yang diturunkan menjadi konsep-konsep yang lebih kecil yang dihubungkan oleh garis penghubung. Kata-kata pada garis penghubung memberikan hubungan antara konsep-konsep. Pohon jaringan cocok digunakan untuk memvisualisasikan informasi sebab-akibat, hirarki, prosedur yang bercabang, dan istilah-istilah yang berkaitan yang dapat digunakan untuk menjelaskan hubunganhubungan.

\section{b. Rantai Kejadian (Events Chain)}

Peta konsep rantai kejadian dapat digunakan untuk menguraikan suatu urutan kejadian, langkah-langkah dalam suatu prosedur, atau tahap-tahap suatu proses. c. Peta Konsep Siklus (Cycle Concept Map)

Dalam peta konsep siklus, rangkaian kejadian tidak menghasilkan suatu hasil akhir. Kejadian akhir pada rantai itu menghubungkan kembali ke kejadian awal. Seterusnya kejadian akhir itu menghubungkan kembali ke kejadian awal siklus itu berulang dengan sendirinya dan tidak ada akhirnya. Peta konsep siklus cocok diterapkan untuk menunjukan hubungan bagaimana suatu rangkaian kejadian berinteraksi untuk menghasilkan suatu kelompok hasil yang berulang-ulang.

\section{d. Peta Konsep Laba-laba (Spider Concept Map)}

Peta konsep laba-laba dapat digunakan untuk curah pendapat. Dalam melakukan curah pendapat ide-ide berasal dari suatu ide sentral, sehingga dapat memperoleh sejumlah besar ide yang bercampur aduk. Banyak dari ide-ide tersebut berkaitan dengan ide sentral namun belum tentu jelas hubungannya satu sama lain. Peta konsep laba-laba dalam batas tertentu mirip dengan mind map dari Buzan.

\section{Meningkatkan Kemampuan Analisis}

Penelitian tentang peta konsep telah banyak dimanfaatkan untuk meningkatkan dan mengukur daya analisis peserta didik. Salah satunya yang telah diteliti oleh Yani (2010) tentang efektivitas mapping concept dalam meningkatkan daya nalar siswa. Cara pemanfataan mapping concept melalui sintaks tahapan pembelajaran Derivative Subsumption, Connecting concept, Construc of new Knowledge, dan Reflective. Mapping concept terjadi pada tahap proses koneksi yang dapat dilakukan secara individual maupun kelompok. Penelitian lain, Yani (2012) juga memanfaatkan teknik mapping concept dalam meningkatkan jarak nalar siswa pada mata pelajaran geografi di SMA. Jarak nalar yang merupakan penyederhanaan dari perhitungan peta konsep (mapping concept) yang dilakukan oleh Novak (1985) dan Dahar (1986) dapat dijadikan alat ukur dalam menguji kemampuan siswa dalam menalar sesuatu.

Salah satu ciri yang dapat diamati dari kemampuan analitis adalah ketika seseorang mampu menguraikan dan atau memisahkan suatu hal ke dalam bagian-bagiannya (atau sebaliknya) serta dapat mencari keterkaitan antara bagian-bagian tersebut. Lebih rumit dari itu, proses analisis juga dapat diamati dari kecepatannya menjelaskan komponen suatu sistem dan saling berhubungan dan organisasinya.

Suherman dan Sukjaya (1990: 49) menyatakan bahwa kemampuan analisis adalah kemampuan untuk merinci atau menguraikan suatu masalah (soal) menjadi bagian-bagian 
yang lebih kecil (komponen) serta mampu untuk memahami hubungan diantara bagian-bagian tersebut. Bloom yang dikutip oleh Sudrajat (2011) menyatakan bahwa kemampuan analisis terdiri dari tiga kelompok, yaitu kemampuan mengidentifikasi unsur-unsur komponen, menganalisis hubungan, dan menganalisis prinsipprinsip organisasi.

Untuk meningkatkan kemampuan berfikir analisis, sejumlah ahli mengajukan teori pembelajarannya. Salah satunya adalah Sparrow, Tim and Jo Maddock yang dikutip oleh Dharma (2007:301) yang menjelaskan tentang sistem pembelajaran reflektif adalah, The practice of reflective learning is part of a continuous process of learning and developing: I become aware of my next experience, reflect upon it and evaluate it in relation to my other experiences and reinforce or revise my self knowledge. (Sparrow, Tim and Jo Maddock, 2006).

Inti dari penyataan itu adalah kegiatan merefleksi dan mengevaluasi dalam kaitannya dengan pengalaman yang telah dilakukan di masa lalu akan memperkuat atau atau merevisi pengetahuan di masa yang akan datang. Mungkin yang dimaksud dengan reinforce or revise adalah akan mengalami proses asimilasi atau sebaliknya akomodasi. Sebagaimana dikemukakan oleh Tebow (Dharma, 2007), Langkah praktis pembelajaran reflektif antara lain sebagai berikut.

a. Menghadirkan masalah yang dirasa tidak nyaman oleh peserta didik atau oleh masyarakat. Bisa juga dengan mengkritik

\section{METODE PENELITIAN}

Penelitian ini menggunakan metode eksperimen untuk uji coba efektivitas pembelajaran dengan peta konsep terhadap peningkatan daya analisis mahasiswa Jurusan Pendidikan Geografi angkatan 2010 atau yang mengontrak matakuliah Perencanaan Pembelajaran Geografi tahun 2011/2012. Desain penelitian PretestPostest Control Group Design, yaitu desain yang pelaksanaannya diawali dari pemilihan dua kelompok (kelas) yang setara, kemudian kedua kelas tersebut diberi pretest untuk mengetahui keadaan awal yaitu adakah perbedaan antara kelompok eksperimen dan kelompok kontrol. terhadap berbagai kebijakan yang mengancam kehidupan.

b. Identifikasi dan mengklarifikasi terhadap masalah yang telah dikemukankan

c. Keterbukaan dan meningkatkan akses terhadap informasi baru untuk mengatasi masalah. Keterbukaan terhadap informasi baru dari sumber internal dan eksternal, dengan kemampuan untuk mengamati dan mengambil dari berbagai perspektif. Kegiatan ini termasuk berbicara secara terbuka dengan orang lain, melihat keputusan yang mungkin dari semua pihak, membaca literatur terkait dan tidak terkait dengan masalah yang dihadapi dan bertanya pada diri sendiri.

d. Mengajukan resolusi. Tahap ini adalah tahap mengajukan jawaban atas masalah yang sedang dihadapi sebagaimana telah diajukan pada tahap identifikasi masalah.

e. Menetapkan kesinambungan diri dengan masa sekarang, dan masa depan. Peserta didik diminta untuk melihat terhadap dirinya untuk menyiapkan perubahan perilaku di masa depan.

f. Pengambilan keputusan yaitu peserta didik dilatih untuk memutuskan tindak yang akan diambil berdasarkan hasil dari proses reflektif.

Dalam proses reflektif akan diarahkan agar peserta didik mampu melakukan analisis terhadap masalah yang sedang dihadapinya berdasarkan pengalamannya masa lalu. Secara bertahap akan meningkatkan kemampuan analisis peserta didik.

\section{HASIL DAN PEMBAHASAN \\ Hasil Penelitian}

Untuk menggambarkan pengaruh penggunaan peta konsep kaitannya dengan usaha meningkatkan daya analisis, penelitian ini dilakukan melalui tiga tahap yaitu tahap identifikasi pemahaman mahasiswa terhadap kemampuan analisis, kesulitan mahasiswa dalam menggunakan peta konsep, dan efektivitas penggunaan peta konsep dalam meningkatkan daya analisis mahasiswa khususnya pada materi perkuliahan Perencanaan Pembelajaran Geografi Tahun Akademik 2012/2013. 


\section{Tingkat Kemampuan Analisis}

Identifikasi pemahaman mahasiswa terhadap kemampuan analisis diukur dengan sebuah test yang pertanyaannya seputar indikator kemampuan analisis yang diturunkan dari pendapat Bloom (Sudrajat, 2011).

Hasil test di lapangan menunjukkan bahwa dari 41 orang respondem yang berasal dari mahasiswa yang mengontrak mata kuliah
Perencanaan Pembelajaran Geografi Tahun Akademik 2012/2013 diperoleh data sebagai berikut. Kemampuan mahasiswa dalam kompetensi menganalisis hanya 46,22\% dengan rincian kemampuan menganalisis unsur-unsur $34,58 \%$, kemampuan menganalisis hubungan $39,92 \%$, dan kemampuan menganalisis prinsipprinsip organisasi $25,51 \%$.

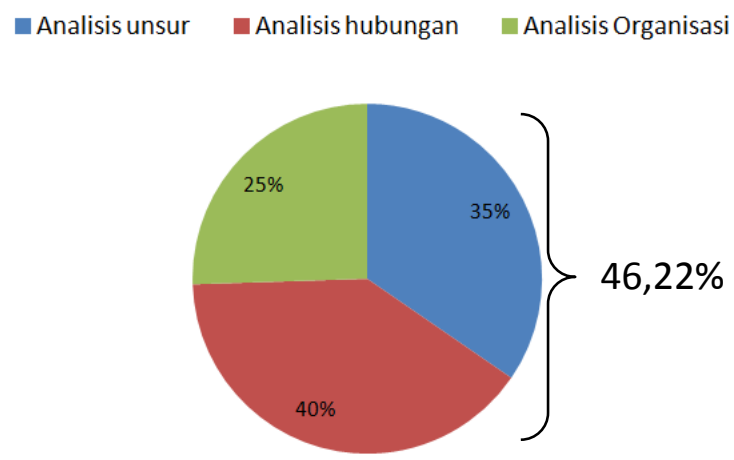

Gambar 1 Grafik pie tentang proporsi kemampuan analisis mahasiswa dari 46,22\% (Penelitian, 2013)

Berdasarkan grafik di atas, maka kemampuan analisis mahasiswa relatif masih rendah karena hanya 46,22\% saja dari yang seharusnya $100 \%$. Jika dilihat dari proporsinya, maka kemampuan menganalisis hubungan ternyata relatif lebih baik dari yang lainnya. Pada urutan kedua adalah kemampuan menganalisis unsur-unsur dan paling rendah adalah analisis organisasi. Kemampuan organisasi memang lebih rumit dari yang kedua pertama, karena di dalamnya perlu apresiasi yaitu mengenal bentuk dan pola karya seni dalam rangka memahami yang abstrak dan tidak akan sama persepsinya antara satu orang dengan orang lain. Begitu pula kemampuan untuk mengetahui maksud dari pengarang, sudut pandang atau ciri berpikirnya dan perasaan yang dapat diperoleh dalam karyanya. Apalagi kemampuan untuk melihat teknik yang digunakan dalam menyusun materi yang bersifat persuasif seperti advertensi dan propaganda.

\section{Pelaksanaan Tindakan Eksperimen dan} Kesulitan dalam Pengembangan Peta Konsep

Langkah kedua dari proses menelusuri kemampuan menganalisis mahasiswa adalah selama proses eksperimen. Kegiatan ekperimen dilakukan pada kelas eksperimen dengan proses pembelajaran menggunakan peta konsep. Skenario pembelajaran secara singkat sebagai berikut.

a) Dosen menyiapkan bahan ajar yang perlu dipelajari oleh mahasiswa. Sebelum diminta dipelajari, dosen memberi pengantar bahwa pokok-pokok matakuliah PPG sekitar 11 (sebelas) topik.

(1) Konsep belajar behavioristik

(2) Proses belajar menurut konsep kognitivistik

(3) Konsep belajar humanistik

(4) Konsep belajar konstruktivistik

(5) Prinsip-prinsip belajar

(6) Komponen pembelajaran

(7) Desain pembelajaran (instructional design)

(8) Kompetensi Inti dalam Kurikulum 2013

(9) Model saintifik

(10) Pembelajaran Berbasis Masalah

(11) Media dan sumber belajar 
b) Diskusi tentang model-model peta konsep yang dapat dibuat oleh mahasiswa dalam mengerjakan tugas. Pada pertemuan tersebut, mahasiswa juga membahas bagian wacana yang akan dibuat dalam peta konsep. Model peta konsep yang diprioritaskan adalah dalam pola:

(1) Pohon jaringan (network tree)

(2) Rantai kejadian (events chain)

(3) Peta konsep siklus (cycle concept map)

(4) Peta konsep laba-laba (spider concept map)

Sebelum menyusun peta konsep, dosen menyelenggarakan pretest untuk melihat data awal kuasi eksperimen. Adapun hasil belajar di akhir perkuliahan adalah peta konsep dari masing-masing kelompok.

c) Pada pertemuan berikutnya, kelompok diminta kembali untuk membahas dan membuat peta konsep untuk menyempurnakannya pada media yang berbeda. Kelompok dapat memperkaya langsung pada peta konsep yang telah dibuatnya pada pertemuan sebelumnya.

d) Pertemuan ketiga dan keempat, masingmasing kelompok mempresentasikan hasil peta konsep sambil berdiskusi untuk memperkaya wawasan. Jadi, terjadi proses asimilasi untuk memperluas skema pengetahuan mahasiswa tentang PPG.

e) Dosen menyelenggarakan postest untuk mengukur hasil tindakannya. Soal test sama dengan soal postest. Bentuk soal berupa Pilihan Ganda yang diawali dengan wacana yang sama dengan wacana pengembangan peta konsep. Setelah postest, dosen menyelenggarakan diskusi tentang berbagai kesulitan yang dialami mahasiswa ketika membuat peta konsep.

Hasil wawancara kepada beberapa mahasiswa di kelas eksperimen terkait dengan pengembangan peta konsep penelitian ini adalah sebagai berikut.

a) Mahasiswa mengalami sedikit kesulitan dalam menentukan topik utama yang akan dijadikan titik pusat penyusunan peta konsep. Walaupun pada akhirnya mereka (kelompok) menyepakati segera agar tugas penyusunan peta konsep dapat segera selesai. Kelompok yang sedikit alot menetapkan pokok bahasan tentang komponen pembelajaran, desain pembel-ajaran (instructional design), Kompetensi Inti, dan pendekatan pembelajaran. Kelompok lain tidak mengalami banyak kesulitan.

Tabel 1 Pemanfaatan dan Tambahan Konsep

\begin{tabular}{clccc}
\hline Kel & \multicolumn{1}{c}{ Tema } & $\begin{array}{c}\text { Konsep } \\
\text { disediakan }\end{array}$ & $\begin{array}{c}\text { Konsep yang } \\
\text { digunakan }\end{array}$ & $\begin{array}{c}\text { Konsep } \\
\text { Tambahan }\end{array}$ \\
\hline $\mathbf{1}$ & Behavioristik & 16 & 14 & 6 \\
$\mathbf{2}$ & Kognitivistik & 16 & 16 & 13 \\
$\mathbf{3}$ & Humanistik & 16 & 13 & 32 \\
$\mathbf{4}$ & Konstruktivistik & 16 & 16 & 26 \\
$\mathbf{5}$ & Belajar & 16 & 14 & 17 \\
$\mathbf{6}$ & Kurikulum & 16 & 9 & 41 \\
$\mathbf{7}$ & Desain Pembelajaran & 16 & 15 & 17 \\
$\mathbf{8}$ & Kompetensi Inti & 16 & 16 & 12 \\
$\mathbf{9}$ & Model Saintifik & 16 & 16 & 25 \\
$\mathbf{1 0}$ & Pendekatan Pembelajaran & 16 & 15 & 25 \\
$\mathbf{1 1}$ & Media Dan Sumber Belajar & 16 & 13 & 7 \\
& & & 157 & 221 \\
& & & 14,27 & 20,09 \\
\hline
\end{tabular}

b) Kesulitan lainnya terkait dengan menyusun daftar konsep yang akan dilibatkan dalam peta konsep sebagai pengayaan dari konsep yang telah disediakan. Konsep yang mereka tambahkan masih terbatas dan parsial. c) Kesulitan yang dirasakan oleh mahasiswa adalah menghubungkan antar konsep. Apa yang mereka rasakan ternyata menyusun peta konsep harus memiliki pemahaman yang utuh pada satu topik sehingga dapat mengumpulkan konsep yang serumpun dan 
memisahkan konsep-konsep yang tidak serumpun. Selain itu dalam menghubungkan antar konsep yang berada di luar dari rumpunnya menurut mahasiswa adalah kunci dari pemahaman wacana.

d) Masalah yang terkait dengan teknik pengembangan peta konsep, umumnya mengalami kesulitan dalam menentukan pola gambar yang akan digunakan.

\section{Efektivitas Peta Konsep dalam Meningkat- kan Kemampuan Analisis}

Sebagaimana telah direncanakan bahwa langkah penelitian ini ada lima yaitu pengembangan instrumen dan bahan penelitian, melaksanakan pretest, pelaksanaan pembelajaran (tindakan eksperimen), postest dan menyusun laporan. Berdasarkan rangkaian tersebut, maka bagian ini akan dijelaskan tentang efektivitas penggunaan peta konsep dalam meningkatkan kemampuan analisis mahasiswa yang dilihat dari

Pelaksanaan pembelajaran di kelas eksperimen, mahasiswa diminta untuk membuat peta konsep untuk memahami materi ajar pada perkuliahan yang sedang berjalan. Skenario pokok perkuliahan di kelas eksperimen meminta mahasiswa untuk membuat peta konsep sedangkan di kelas kontrol akan disampaikan secara ceramah. Di akhir eksperimen akan dilakukan pos test untuk melihat pengaruh pembelajaran yang menggunakan peta konsep. Belum dilaksanakan. Setelah data hasil penelitian diolah, selanjutnya dibuat laporan penelitian.

Kondisi pembelajaran dengan menyusun peta konsep sangat kondusif. Setiap kelompok dengan serius mengerjakan tugasnya masingmasing. Mereka seolah berlomba untuk membuat konsep yang sebanyak-banyaknya dan menghubungkan konsep satu dengan yang lainnya dalam peta konsep. Selain itu pada tahap presentasi, antar kelompok juga saling mengkoreksi peta konsep sehingga terjadi proses pembelajaran. Hal yang mungkin menjadi kekurangan dalam penelitian ini, peta konsep tidak diperbaiki setelah dipresentasikan.

Alat yang digunakan untuk membuat peta konsep adalah kertas karton (manila) dan spidol. Mahasiswa membuat peta-peta konsep pada kertas karton secara bebas. Peta konsep yang dibuat mahasiswa selanjutnya diduplikasi dalam software Edraw Mind Map agar dapat terekam dalam file dan dilampirkan dalam laporan penelitian.

Berikut ini ditampilkan data hasil pretes dan postes di kelas eksperimen dan kelas kontrol setelah jumlah mahasiswa di kedua kelas disamakan jumlahnya. Perlu dijelaskan bahwa jumlah kelas ekperimen berjumlah 45 orang sedang kelas kontrol 43 orang. Namun dalam pelaksanaan test dari kedua kelompok tersebut ada yang tidak ikut dari salah satu test, yaitu ikut pretes tetapi tidak ikut postest atau sebaliknya, sehingga data yang tidak lengkap dihapus dalam perhitungan, jadi yang tersisa hanya 37 orang.

Eksperimen yang dilakukan bersifat quasi atau semu. Kuasi eksperimen merupakan metode eksperimen yang tidak memugkinkan peneliti melakukan pengontrolan penuh terhadap variabel dan kondisi eksperimen. Pelaksanaan penelitian dengan kuasi eksperimen dilakukan karena tidak selalu memungkinkan untuk melakukan seleksi subjek secara acak, karena subjek secara alami telah terbentuk dalam satu kelompok utuh (naturally formed intact group), seperti kelompok mahasiswa dalam satu kelas. Kelompokkelompok ini juga sering kali jumlahnya sangat terbatas. Dalam keadaan seperti ini kaidahkaidah dalam penelitian eksperimen murni tidak dapat dipenuhi secara utuh, karena pengendalian variabel yang terkait subjek penelitian tidak dapat dilakukan sepenuhnya, sehingga penelitian harus dilakukan dengan menggunakan intact group. Jadi penelitian kuasi eksperimen menggunakan seluruh subjek dalam kelompok belajar (intact group) untuk diberi perlakuan (treatment), bukan menggunakan subjek yang diambil secara acak. 
Tabel 2. Hasil Pretes dan Postes di Kelas Eksperimen dan Kelas Kontrol

\begin{tabular}{rrrrrrr}
\hline NO & \multicolumn{3}{c}{ KELAS EKSPERIMEN } & \multicolumn{3}{c}{ KELAS KONTROL } \\
\cline { 2 - 7 } & PRETES & POSTES & SELISIH & PRETES & POSTES & SELISIH \\
$\mathbf{1}$ & 23 & 23 & 0 & 17 & 16 & -1 \\
$\mathbf{2}$ & 16 & 23 & 7 & 17 & 17 & 0 \\
$\mathbf{3}$ & 24 & 24 & 0 & 21 & 21 & 0 \\
$\mathbf{4}$ & 24 & 21 & -3 & 16 & 17 & 1 \\
$\mathbf{5}$ & 15 & 20 & 5 & 19 & 18 & -1 \\
$\mathbf{6}$ & 20 & 21 & 1 & 20 & 17 & -3 \\
$\mathbf{7}$ & 14 & 16 & 2 & 20 & 21 & 1 \\
$\mathbf{8}$ & 16 & 18 & 2 & 19 & 20 & 1 \\
$\mathbf{9}$ & 18 & 20 & 2 & 22 & 25 & 3 \\
$\mathbf{1 0}$ & 20 & 20 & 0 & 12 & 14 & 2 \\
$\mathbf{1 1}$ & 25 & 27 & 2 & 20 & 18 & -2 \\
$\mathbf{1 2}$ & 20 & 21 & 1 & 21 & 16 & -5 \\
$\mathbf{1 3}$ & 18 & 22 & 4 & 22 & 17 & -5 \\
$\mathbf{1 4}$ & 19 & 17 & -2 & 20 & 21 & 1 \\
$\mathbf{1 5}$ & 24 & 27 & 3 & 16 & 18 & 2 \\
$\mathbf{1 6}$ & 18 & 21 & 3 & 24 & 25 & 1 \\
$\mathbf{1 7}$ & 22 & 23 & 1 & 21 & 24 & 3 \\
$\mathbf{1 8}$ & 20 & 19 & -1 & 16 & 16 & 0 \\
$\mathbf{1 9}$ & 23 & 24 & 1 & 22 & 26 & 4 \\
$\mathbf{2 0}$ & 23 & 25 & 2 & 16 & 20 & 4 \\
$\mathbf{2 1}$ & 19 & 20 & 1 & 18 & 21 & 3 \\
$\mathbf{2 2}$ & 19 & 20 & 1 & 18 & 17 & -1 \\
$\mathbf{2 3}$ & 20 & 22 & 2 & 21 & 20 & -1 \\
$\mathbf{2 4}$ & 20 & 24 & 4 & 12 & 13 & 1 \\
$\mathbf{2 5}$ & 20 & 20 & 0 & 19 & 19 & 0 \\
$\mathbf{2 6}$ & 16 & 22 & 6 & 19 & 20 & 1 \\
$\mathbf{2 7}$ & 19 & 21 & 2 & 16 & 17 & 1 \\
$\mathbf{2 8}$ & 19 & 20 & 1 & 20 & 22 & 2 \\
$\mathbf{2 9}$ & 19 & 21 & 2 & 19 & 17 & -2 \\
$\mathbf{3 0}$ & 24 & 24 & 0 & 21 & 20 & -1 \\
$\mathbf{3 1}$ & 23 & 25 & 2 & 19 & 17 & -2 \\
$\mathbf{3 2}$ & 18 & 24 & 6 & 17 & 21 & 4 \\
$\mathbf{3 3}$ & 22 & 23 & 1 & 21 & 22 & 1 \\
$\mathbf{3 4}$ & 19 & 22 & 3 & 21 & 24 & 3 \\
$\mathbf{3 5}$ & 20 & 23 & 3 & 22 & 19 & -3 \\
$\mathbf{3 6}$ & 22 & 21 & -1 & 24 & 21 & -3 \\
$\mathbf{3 7}$ & 19 & 23 & 4 & 18 & 17 & -1 \\
& 740 & 807 & 67 & 706 & 714 & 8 \\
\hline $\mathbf{S}$ & 23 & - & 2 & & & \\
\hline
\end{tabular}

Sumber: Hasil penelitian, 2013

Setelah melalui perhitungan statistik 1. Uji T untuk Kelas Eksperimen ((Pre test diperoleh penjelasan sebagai berikut. Post Test)

Paired Samples Statistics

\begin{tabular}{|ll|r|r|r|r|}
\hline & Mean & N & Std. Deviation & Std. Error Mean \\
\hline Pair 1 & sebelum & 20.0000 & 37 & 2.73861 & .45023 \\
& sesudah & 21.8108 & 37 & 2.43627 & .40052 \\
\hline
\end{tabular}

Paired Samples Correlations

\begin{tabular}{|ll|r|r|r|}
\hline & $\mathrm{N}$ & Correlation & \multicolumn{1}{c|}{ Sig. } \\
\hline Pair 1 $\quad$ sebelum \& sesudah & 37 & .658 & .000 \\
\hline
\end{tabular}


Paired Samples Test

\begin{tabular}{|c|c|c|c|c|c|c|c|c|}
\hline & \multicolumn{5}{|c|}{ Paired Differences } & \multirow[b]{3}{*}{$\mathrm{t}$} & \multirow[b]{3}{*}{ df } & \multirow{3}{*}{$\begin{array}{l}\text { Sig. (2- } \\
\text { tailed) }\end{array}$} \\
\hline & \multirow[b]{2}{*}{ Mean } & \multirow{2}{*}{$\begin{array}{c}\text { Std. } \\
\text { Deviation }\end{array}$} & \multirow{2}{*}{$\begin{array}{c}\text { Std. Error } \\
\text { Mean }\end{array}$} & \multicolumn{2}{|c|}{$\begin{array}{l}95 \% \text { Confidence } \\
\text { Interval of the } \\
\text { Difference }\end{array}$} & & & \\
\hline & & & & Lower & Upper & & & \\
\hline $\begin{array}{ll}\text { Pair } & \text { sebel } \\
1 & \text { um - } \\
& \text { sesud } \\
& \text { ah }\end{array}$ & -1.81081 & 2.15816 & .35480 & -2.53038 & -1.09124 & -5.104 & 36 & .000 \\
\hline
\end{tabular}

Hipotesis:

Ho = tidak terdapat perbedaan antara nilai pre test dan post test pada kelompok eksperimen $\mathrm{Ha}=$ terdapat perbedaan antara nilai pre test dan post test pada kelompok eksperimen

Berdasarkan hasil uji statistik dengan menggunakan Uji T untuk sampel berkorelasi (paired sample Test) menunjukkan nilai $\mathrm{t}=$ 5,104 (tanda minus tidak berpengaruh/tidak berarti). Ini berarti nilai tersebut lebih besar dari nilai t tabel yang nilainya $2,029(5,104>2,029)$ pada taraf signifikansi $95 \%$. Kesimpulannya terdapat perbedaan antara nilai pre test dan nilai post test. Kesimpulan yang sama juga diperoleh dari nilai Signifikansi (2-tailed) yang nilainya 0,000 atau lebih kecil dari 0,05 (Sig: $p \leq 0,05$ ), sehingga kesimpulannya adalah Ho ditolak dan Ha diterima atau terdapat perbedaan antara nilai pre test dan post test pada kelompok eksperimen.

\section{Uji T untuk Kelas Kontrol (Pre test - Post Test)}

Paired Samples Statistics

\begin{tabular}{|lc|c|c|c|c|}
\hline & Mean & N & Std. Deviation & Std. Error Mean \\
\hline \multirow{2}{*}{ Pair 1 } & sebelumK & 19.0811 & 37 & 2.77267 & .45582 \\
& setelahK & 19.2973 & 37 & 3.08099 & .50651 \\
\hline
\end{tabular}

Paired Samples Correlations

\begin{tabular}{|ll|c|c|c|}
\hline & $\mathrm{N}$ & Correlation & Sig. \\
\hline Pair 1 & sebelumK \& setelahK & 37 & .683 & .000 \\
\hline
\end{tabular}

Paired Samples Test

\begin{tabular}{|c|c|c|c|c|c|c|c|c|}
\hline & \multicolumn{5}{|c|}{ Paired Differences } & \multirow[b]{3}{*}{$\mathrm{t}$} & \multirow[b]{3}{*}{ df } & \multirow{3}{*}{$\begin{array}{l}\text { Sig. (2- } \\
\text { tailed) }\end{array}$} \\
\hline & \multirow[b]{2}{*}{ Mean } & \multirow{2}{*}{$\begin{array}{c}\text { Std. } \\
\text { Deviation }\end{array}$} & \multirow{2}{*}{$\begin{array}{l}\text { Std. Error } \\
\text { Mean }\end{array}$} & \multicolumn{2}{|c|}{$\begin{array}{l}95 \% \text { Confidence } \\
\text { Interval of the } \\
\text { Difference }\end{array}$} & & & \\
\hline & & & & Lower & Upper & & & \\
\hline $\begin{array}{c}\text { Pair } 1 \text { sebelum } \\
\mathrm{K}- \\
\text { setelah } \\
\mathrm{K}\end{array}$ & -.21622 & 2.34681 & .38581 & -.99868 & .56625 & -.560 & 36 & .579 \\
\hline
\end{tabular}

Hipotesis:

Ho $=$ tidak terdapat perbedaan antara nilai pre test dan post test pada kelompok kontrol $\mathrm{Ha}=$ terdapat perbedaan antara nilai pre test dan post test pada kelompok kontrol 
Berdasarkan hasil uji statistik dengan menggunakan Uji T untuk sampel berkorelasi (paired sample Test) menunjukkan nilai $\mathrm{t}=$ 0,560 . Ini berarti nilai tersebut lebih kecil dari nilai $\mathrm{t}$ tabel yang nilainya $2,029 \quad(-0,560>$ 2,029) pada taraf signifikansi $95 \%$. Kesimpulannya adalah terdapat perbedaan yang signifikan antara nilai pre test dan nilai post test. Kesimpulan yang sama diperoleh dari nilai signifikansi dua sisi (2-tailed) yang nilainya 0,579 atau lebih besar dari 0,05 (Sig: p > 0,05), sehingga kesimpulannya adalah Ho diterima dan Ha ditolak atau tidak terdapat perbedaan antara nilai pre test dan post test kelompok kontrol.

\section{Perbandingan Selisih Nilai Kelompok}

\section{Eksperimen dan Kontrol}

Pengaruh dari penggunaan model peta konsep terhadap nilai siswa dapat dilihat dari perbandingan selisih pre test-post test antara kelompok eksperimen dan kelompok kontrol. Untuk kepentingan tersebut digunakan Uji T untuk sampel yang tidak berkorelasi (independent sampel t-test) karena perbandingan dilakukan pada dua kelompok sampel yang berbeda.
Hipotesis:

Ho = tidak terdapat perbedaan selisih nilai pre test dan post test pada kelompok kontrol/ Tidak ada pengaruh yang signifikan penggunaan model peta konsep terhadap hasil belajar siswa. $\mathrm{Ha}=$ terdapat perbedaan selisih nilai pre test dan post test pada kelompok kontrol. Ada pengaruh yang signifikan penggunaan model peta konsep terhadap hasil belajar siswa.

Hasil uji statistic menunjukkan nilai $\mathrm{t}$ hitung sebesar 3,042, sedangkan t tabel 2,029, sehingga $t$ hitung lebih besar dari t tabel. Ini berarti Ho ditolak dan Ha diterima. Dari kolom Uji $\mathrm{T}$ menunjukkan nilai $\mathrm{P}=0,003$ untuk uji dua sisi (2-tailed). Karena nilai $\mathrm{P}$ lebih kecil dari nilai $\alpha=0,05$, maka Ho ditolak dan $\mathrm{Ha}$ diterima, sehingga terdapat perbedaan antara kelas eksperimen dengan kelas kontrol setelah diaplikasilan model peta konsep pada kelas eksperimen. Rata-rata selisih nilai pre test dan post test pada kelas $(1,8108)$ eksperimen lebih besar dari kelas kontrol (0,2162). Jadi, ada pengaruh yang signifikan penggunaan model peta konsep terhadap hasil belajar siswa.

Group Statistics

\begin{tabular}{|ll|r|r|r|r|}
\hline \multicolumn{2}{|c|}{ BandingEksKontrol } & N & Mean & Std. Deviation & Std. Error Mean \\
\hline SelisihEksKontr & Kelompok Eksperimen & 37 & 1.8108 & 2.15816 & .35480 \\
ol & Kelompok Kontrol & 37 & .2162 & 2.34681 & .38581 \\
\hline
\end{tabular}

Independent Samples Test

\begin{tabular}{|c|c|c|c|c|c|c|c|c|c|}
\hline & \multicolumn{2}{|c|}{$\begin{array}{l}\text { Levene's Test } \\
\text { for Equality of } \\
\text { Variances }\end{array}$} & \multicolumn{7}{|c|}{ t-test for Equality of Means } \\
\hline & \multirow[b]{2}{*}{$\mathrm{F}$} & \multirow[b]{2}{*}{ Sig. } & \multirow[b]{2}{*}{$\mathrm{t}$} & \multirow[b]{2}{*}{ df } & \multirow{2}{*}{$\begin{array}{c}\text { Sig. } \\
(2- \\
\text { tailed })\end{array}$} & \multirow{2}{*}{$\begin{array}{c}\text { Mean } \\
\text { Differen } \\
\text { ce }\end{array}$} & \multirow{2}{*}{$\begin{array}{c}\text { Std. Error } \\
\text { Differenc } \\
\mathrm{e}\end{array}$} & \multicolumn{2}{|c|}{$\begin{array}{l}\text { 95\% Confidence } \\
\text { Interval of the } \\
\text { Difference }\end{array}$} \\
\hline & & & & & & & & Lower & Upper \\
\hline $\begin{array}{ll}\text { Selisih } & \text { Equal } \\
\text { EksKon } & \text { variances } \\
\text { trol } & \text { assumed } \\
& \\
& \text { Equal } \\
& \text { variances } \\
& \text { not } \\
& \text { assumed }\end{array}$ & .734 & .395 & 3.042 & 71.500 & .003 & 1.59459 & .52415 & .54972 & 2.63947 \\
\hline
\end{tabular}

\section{Pembahasan Penelitian}

Data hasil penelitian menunjukkan bahwa ada sedikit peningkatan kemampuan mahasiswa dalam melakukan analisis terhadap materi perkuliahan PPG. Dengan dengan demikian dapat dikatakan bahwa ada pengaruh 
penggunaan peta konsep terhadap kemampuan analisis berpikir. Proses peningkatan kemampuan tersebut disebabkan oleh adanya optimalisasi kemampuan otak kiri dan kanan secara bersamaan. Sebagaimana diketahui bahwa otak manusia memiliki otak besar (cerebrum) yang terdiri dari belahan kiri dan belahan kanan. Keduanya memiliki fungsi yang berbeda, belahan kiri berfungsi logika, rasio, matematik, menulis, membaca dan atau Intelligence Quotient (IQ) sedangkan belahan kanan berfungsi intuitif, merasakan, apresiasi seni, memadukan, dan atau bersufat Emotional Quotient (EQ). Pada otak kanan ini pula terletak kemampuan intuitif, kemampuan merasakan, memadukan. Ketika kedua fungsi otak tersebut seimbang, maka kemampuan analisis seseorang akan lebih optimal.

Wahidin (2010) dalam artikelnya Peta Konsep Untuk Melatih Ketrampilan Berpikir yang diposting di www.infodiknas.com mengatakan bahwa dengan peta konsep, guru dapat membuat suatu program pengajaran lebih terarah dan berjenjang, sehingga dalam pelaksanaan proses belajar mengajar dapat meningkatkan daya serap siswa terhadap materi yang diajarkan. Skemp yang diposting pada http://www.grahamtall.co.uk mengajukan gagasan tentang tingkatan daya serap (the levels of understanding) yaitu tingkat pemahaman instrumental dan pemahaman relasional. Pemahaman instrumental bersifat linier dan dapat diilustrasikan seperti mahasiswa mengerjakan matematika dengan rumus dan jalan pikiran sesuai dengan apa yang diajarkan oleh dosen. Sedangkan pemahaman relasional adalah pemahaman yang menghubungkan dengan konsep lain. Ilustrasinya adalah seperti mahasiswa mengerjakan matematik dengan rumus yang sama tetapi jalan untuk menjawab soal tersebut berbeda dengan apa yang diajarkan oleh dosennya. Tentu saja walaupun cara yang berbeda tetapi tetap hasilnya juga benar.

Kemampuan otak kiri barangkali sama dengan cara berpikir pemahaman instrumental sedangkan otak kanan sama dengan cara berpikir relasional. Proses berpikir relasional memiliki kemampuan untuk lebih original dan inovatif. Cara berpikir inilah yang kemudian menganggap bahwa peta konsep adalah instrumen yang terbaik untuk memadukan dua kemampuan otak kiri dan otak kanan.

Apakah pembelajaran melalui peta konsep memiliki posisi teori yang kokoh? Pertanyaan ini tentu saja akan dijawab dengan pasti yaitu sangat kokoh. Peta konsep merupakan gambaran skema pengetahuan yang dimiliki oleh seseorang yang setiap saat berkembang atau bertambah seiring dengan penambahan konsep dalam skemanya. Dari berbagai sumber bacaan, ternyata landasan pembelajaran melalui peta konsep adalah konstruktivisme yang secara eksplisit berdiri dari aliran kognitif-nya Jean Piaget, yaitu yang terkait dengan proses akomodasi dan asimilasi. Individu akan mengkonstruksi pengetahuan baru dari pengalamannya ditambah dengan informasi baru dari lingkunganya. Asimilasi akan terjadi jika konsep baru menambah skema tanpa ada hambatan sedangkan akomodasi dapat dipahami sebagai suatu mekanisme inkubasi dari pengetahuan baru yang belum cocok, bisa terjadi untuk disesuaikan, direvisi, atau bahkan ditolak. Penolakan terhadap konsep baru juga bermanfaat untuk mengukuhkan skema yang telah kokoh.

Dalam peta konsep akan nampak digambarkan ketika asimilasi dan akomodasi bekerja. Namun demikian, ada hambatan teknis ketika mahasiswa menempatkan konsep pada tempat yang tepat. Beberapa konsep terkadang dipaksakan ditempatkan pada koneksi yang keliru hanya untuk memenuhi point agar banyak konsep yang ditampilkan, padahal bisa jadi mereka tidak memahami secara rasional.

Bagaimana implikasi pemanfaatan peta konsep terhadap perkuliahan? Implikasi pertama adalah sistem perkuliahan yang biasa menggunakan pendekatan deduktif perlu diubah dengan pendekatan yang bersifat induktif. Resikonya struktur berpikir mahasiswa yang terbiasa dengan berpikir terstruktur harus terbiasa dengan berpikir acak dan terkadang tidak terstruktur. Pendekatan deduktif adalah pendekatan pembelajaran yang diawali dari penyampaian informasi yang bersifat umum. Biasanya guru akan memulai pembelajarannya dari pengertian atau definisi tentang sesuatu, menguraikan kedalam bagian-bagian yang lebih rinci. Guru akan menguraikan secara runtut 
tentang sesuatu yang perlu diketahui oleh siswa, sementara itu, siswa cenderung pasif mendengarkan. Siswa kurang diberi kesempatan untuk mengikuti alur pikir penjelasan guru. Sebaliknya, pada pendekatan induktif, guru akan memulai penjelasan dari keadaan atau kenyataan yang terjadi di sekitar lingkungan siswa. Guru mengajak siswa untuk menunjukkan fakta, lalu diklasifikasi atau dikelompokkan, dan selanjutnya dirangkum menjadi suatu informasi atau pengetahuan yang baru bagi siswa / peserta didik.

Implikasi kedua adalah perubahan pada tata cara pengemasan materi dari sekuens struktural menjadi sekuens konsentris. Sekuens struktural yang biasa dilakukan oleh dosen adalah sesuai silabus sebagaimana telah dirumuskan sebelumnya. Sedangkan sekuens konsentris akan diacak sesuai konteks pembahasan yang terkait. Seperti pada parkatek penelitian ini, dari 11 materi pokok yang berbeda akan dipelajari oleh masing-masing kelompok tetapi secara bersama-sama dalam satu waktu.

Implikasi lainnya adalah penyediaan media atau alat bantu pembelajaran. Dosen perlu menyediakan alat berupa papan tulis atau kertas planel. Alat lainnya untuk menuliskan konsep esensial, guru perlu menyediakan guntingan kertas ukuran kira-kira $7 \mathrm{~cm}$ x $20 \mathrm{~cm}$. Selain itu tentu alat tulis seperti spidol warna dan solatif untuk menempel kertas konsep di depan kelas. Dengan demikian, akan membutuhkan biaya yang lebih banyak dari yang biasanya sehingga modal yang dibutuhkan pun tidak sedikit.

\section{PENUTUP}

Berdasarkan hasil penelitian dan mengacu pada masalah yang diajukan dalam penelitian ini, maka dapat disimpulkan sebagai berikut.

a. Kemampuan mahasiswa dalam menganalisis relatif masih rendah karena hanya 46,22\% saja dari yang seharusnya $100 \%$. Jika dilihat dari proporsinya, kemampuan menganalisis hubungan ternyata relatif lebih baik dibandingkan kemampuan menganalisis unsur-unsur sistem dan analisis organisasi. Jika dikaitkan dengan teori tingkatan daya serap (the levels of understanding), maka mahasiswa (subjek penelitian) memiliki potensi dalam pemahaman yang bersifat relasional.

b. Mahasiswa relatif mengalami kesulitan dalam menggambar peta konsep yaitu pada saat menentukan topik utama, menyusun daftar konsep yang akan dilibatkan dalam peta konsep, menghubungkan antar konsep, dan teknik pengembangan peta konsep. Berdasarkan hasil penelitian, mahasiswa belum terbiasa untuk mencari tema pikiran pada suatu wacana atau topik pembicaraan.

c. Berdasarkan hasil penelitian, maka penggunaan peta konsep ternyata berpengaruh terhadap kemampuan analisis. Dengan fakta ini dapat dijadikan dasar bahwa belajar yang memanfaatkan belakan otak kanan dan kiri secara bersamaan lebih optimal. Belahan otak kiri yang berfungsi logika, rasio, matematik, menulis, membaca dan atau Intelligence Quotient(IQ) sedangkan belahan kanan berfungsi intuitif, merasakan, apresiasi seni, memadukan, dan atau bersifat Emotional Quotient (EQ).

Secara umum penelitian ini dapat membuktikan efektivitas penggunaan peta konsep dalam meningkatkan kemampuan analisis. Untuk dapat dikembangkan lebih lanjut oleh kalangan dosen di universitas dapat disarankan.

a. Perlu sosialisasi kepada para dosen tentang penggunaan peta konsep sebagai alternatif dalam peningkatkan kualitas perkuliahan. Sosialisasi dapat dilakukan melalui seminar atau dalam bentuk lainnya

b. Selain memiliki keunggulan, bisa jadi masih memiliki kelemahan, seperti banyak memakan waktu dan biaya. Oleh karena itu, sampai saat ini penulis hanya menyarankan agar peta konsep hanya sebagai alternatif untuk digunakan sekali-kali saja sebagai variasi perkuliahan.

c. Bagi mahasiswa, perkuliahan dengan penggunaan peta konsep adalah tantangan belajar yang sangat tinggi. Bagi yang suka dengan ilmu pengetahuan dan informasi baru, perkuliahan dengan metode ini hendaknya dijadikan petualangan yang jauh bermakna dibandingkan hanya membaca buku referensi. 


\section{DAFTAR PUSTAKA}

Bhattacharya, M. 2002. Creating a Meaningful Learning Environment Using ICT. Instructional Science Academic Group, National Institute of Education (NIE), Nanyang Technological University. May 2002, Vol. 5 No. 3.

Dahar, RW. 2011. Teori-teori belajar dan Pembelajaran. Jakarta. Penerbit Erlangga.

DePoter, B., Hernacki, M. 1999. Quantum Learning Membiasakan Belajar Nyaman dan Menyenangkan. Bandung. Penerbit Kaifa.

Dharma, Lala Herawati. 2007. Brain Based Teaching: Merancang Kegiatan Belajar Mengajar Yang Melibatkan Otak, Emosional, Sosial, Kognitif, Kinestetik dan Reflektif. Bandung: Kaifa.

Hergenhahn, B.R dan Olson, MH. 2008. Theories of Learning (Terjemahan). Jakarta. Kencana Prenada Media Group.

Joice, B, \& Weil, M. 1980. Models of teaching. New Jersey: Englewood Cliffs, Publ. Marzano RJ \& Kendal JS (1996). Designing standard-based districs, schools, and classrooms. Vriginia: Assiciation for Supervision and Curriculum Development.

Komalasari, 2010. Pembelajaran Kontekstual Konsep dan Aplikasi. Bandung, Refika Aditama.

Kuswana, WS. 2012. Taksonomi Kognitif Perkembangan Ragam Berpikir. Bandung. PT. Remaja Rosdakarya.

Novak, J.D. 1998. Learning, Creating, and Using Knowledge: concept Map as Facilitative Tools in Schools and Corporations. Mahwah, New Jersey London. Lawrence Erlbaum Associates, Publishers.

Reece, I and Walker, S. 1997. Teaching Traning and Learning a practical Guide - Third Edition. Sunderland, Tyne and wear SR2 7BN. Business Education Publishers.
Reigeluth, Charles M, 1987. Instruksional Theories in Action, Hilsdale, New JerseyHove and London: Lawrence Erlbaum, Associates, Publisher.

Sagala, S. 2005. Konsep dan Makna Pembelajaran. Bandung. Penerbit Alfabeta.

Sanjaya, W. 2006. Strategi Pembelajaran Berorientasi Standar Proses Pendidikan. Jakarta. Kencana Prenada Media.

Skemp, R.R. (tanpa tahun). Relational Understanding and Instrumental Understanding. Artikel. Tesedia On line: http://www.grahamtall.co.uk

Suherman, E. dan Sukjaya, Y. (1990). Petunjuk Praktis untuk Melaksanakan Evaluasi Pendidikan Matematika. Bandung: Wijayakusumah 157.

Sumaatmadja, N. 1997. Metodologi Pengajaran Geografi. Jakarta. Bumi Aksara.

Suparno, P. 1997. Filsafat Konstruktivisme dalam Pendidikan, Yogyakarta. Kanisius.

Wahidin, A. 2010. Peta Konsep Untuk Melatih Ketrampilan Berpikir. Artikel. Tersedia on line www.infodiknas.com

Wiryawan, Sri Anitah dan Noorhadi. Strategi Belajar Mengajar. Jakarta: UT, 1999

Yani, A. 2010. Pengembangan Model Meaningful Learning Untuk Meningkatkan Daya Nalar Siswa Melalui Aplikasi Mind Map Pada Mata Pelajaran Geografi Di SMA. Desertasi. Sekolah Pascasarjana Universitas Pendidikan Indonesia.

Yani, A. 2012. Pengukuran Jarak Nalar Peserta Didik Melalui Mapping Concept Sebagai Landasan Pengembangan Model Meaningful Learning (Studi Kasus Pada Pembelajaran Geografi di SMAN 19 Bandung). Penelitian. Universitas Pendidikan Indonesia. 